\title{
Griya Boedaya: komoditas wahana berliterasi budaya sebagai wujud pengenalan budaya lokal di Jawa Timur
}

\author{
Iffa Maisyaroh ${ }^{1}$, Silvi Oktavia ${ }^{2}$ \\ ${ }^{12}$ Program Studi Ilmu Perpustakaan, Universitas Negeri Malang \\ Jl. Semarang No.5, Lowokwaru, Malang, Jawa Timur, Indonesia 65145 \\ Email: 1maisyarohiffa@gmail.com, 20.silvi.oktavia@gmail.com
}

Received: November 2018; Accepted: June 2019; Published: June 2019

\begin{abstract}
The existing knowledge in society has not been spread explicitly. Thus local knowledge is still unknown to the people in the region itself. This study aimed to provide information related to the dissemination of local knowledge applied to cultural literacy programs form: ideas, behavior, and artifacts or works. The kind of the idea is stated in a paper, the behavior is shown in community activities, and artifacts are contained in works in the form of objects as results of activities and actions. The main focus is on basic human needs: clothing and food applied through Griya Boedaya tour. Clothing consists of typical East Javanese fabrics, while food consists of East Javanese specialties. The culture produced reflects the characteristics of the environment. Thus it has features standing out that becomes the identity of the local community's culture. In the East Java region, knowledge is an invisible or intangible local asset owned by people in the area. This study used the literature method with qualitative approach by searching for books, e-journals, proceedings, thesis and articles. Results of the people's knowledge in the form of typical food and unique clothing were a manifestation of people's expression of their environment. Griya Boedaya introduces local cultures such as regional cloth and cuisine and is a tourist means which introduces history, creation process, work systems, tools used, and the use and philosophy of local cultural products. Hopefully, the cultural literacy tour will enable people to recognize, know, and understand their culture with easy-to-understand and fun methods.
\end{abstract}

Keywords: Griya Boedaya; Culture; Cultural literacy; Tourism; Indigenous knowledge

\begin{abstract}
Abstrak
Pengetahuan di masyarakat belum tersebar secara eksplisit. Pengetahuan lokal masih kurang dikenali masyarakat di daerahnya sendiri. Penulisan ini bertujuan memberikan informasi terkait penyebaran pengetahuan lokal yang diterapkan pada program literasi budaya berupa gagasan, tingkah laku dan artefak atau karya. Wujud gagasan dituangkan dalam karya tulis, tingkah laku dituangkan dalam aktivitas masyarakat dan artefak dituangkan dalam karya berbentuk benda dari hasil aktivitas dan perbuatan. Fokus utama penulisan ini pada kebutuhan pokok manusia yang diterapkan melalui wisata Griya Boedaya, di antaranya sandang dan pangan. Sandang berupa kain khas Jawa Timur dan pangan berupa masakan khas dari Jawa Timur. Kebudayaan yang dihasilkan mencerminkan karakteristik lingkungan daerah Jawa Timur sehingga memiliki ciri khas dan menjadi identitas kebudayaan masyarakat setempat. Pengetahuan masyarakat Jawa Timur merupakan aset lokal yang tidak dilihat (intangible asset) masyarakat daerah tersebut. Penelitian ini menggunakan metode penelitian studi literatur melalui pendekatan kualitatif berupa pencarian sumber tertulis dari buku, ejournal, prosiding, skripsi dan artikel lainnya. Hasil dari pengetahuan masyarakat Jawa Timur berupa makanan dan pakaian khas bentuk ekspresi masyarakat. Griya Boedaya merupakan tempat wisata pengenalan budaya lokal seperti kain khas dan masakan daerah. Wahana yang ditampilkan pada Griya Boedaya meliputi pengenalan sejarah, proses penciptaan, sistem pengerjaan, alat yang digunakan, penggunaan dan filosofi dari produk budaya setempat. Literasi budaya melalui wisata Griya Boedaya diharapkan masyarakat mampu untuk mengenalkan dan memberikan pemahaman budaya melalui metode yang mudah dipahami dan menyenangkan.
\end{abstract}

Kata Kunci: Griya Boedaya; Budaya; Literasi budaya; Wisata; Pengetahuan lokal 


\section{PENDAHULUAN}

Indonesia merupakan negara yang memiliki keberagaman suku, agama, ras dan adat istiadat. Hal ini menjadikan Indonesia memiliki kekayaan dalam budaya berupa kearifan lokal yang khas tiap daerah. Ode (2015) dalam Arwansyah, Suwandi, and Widodo (2017) bahkan mengatakan kalau, "Nilai yang terkandung dalam kebudayaan lokal merupakan aset bangsa yang tak ternilai harganya." Kebudayaan dianggap sebagai aset bangsa yang tak ternilai harganya dikarenakan kebudayaan sebagai salah satu sumber pengetahuan masyarakat dalam mengenal tradisi dan sejarah suatu daerah.

"Globalisasi dianggap sebagai pintu untuk melangkah ke dunia luar dengan cara berinteraksi dengan berbagai negara" (Suneki, 2012). Pada era globalisasi memungkinan membaurnya segala aspek kehidupan karena sifatnya yang tidak terbatas oleh jarak dan waktu. Masuknya globalisasi di segala aspek ini mengakibatkan dampak positif dan negatif. Dampak positif yang dialami yakni semakin canggihnya teknologi dan pengetahuan. Hal ini berbanding terbalik dengan dampak negatif yang dialami yakni tergerusnya budaya akibat dari kecanggihan teknologi dan pengetahuan tersebut. Dampak negatif bisa terlihat dari masyarakat yang lebih mengenal budaya baru daripada budaya yang sudah ada.

Kedua dampak tersebut muncul dengan cepat karena penggunaan teknologi informasi yang semakin meluas sehingga pengaruh dari budaya luar yang tersebar dengan luas. Justiani (2009) dalam Mubah (2011) malah mengatakan bahwa, "Globalisasi beriringan dengan modernisasi yang menyebar ke seluruh penjuru dunia untuk memerankan sebuah revolusi sosial atau masuk ke semua sudut kehidupan seperti mengaburkan batas tradisional." Untuk contoh, cara berpakaian masyarakat yang lebih menggunakan produk dari luar negeri karena dianggap lebih trendi daripada menggunakan produk khas dari dalam negeri. Masyarakat yang tidak bisa menyaring budaya masuk dan berbeda dengan budaya kita maka mengakibatkan masyarakat mengalami krisis terhadap pengetahuan budaya dan pengklaiman budaya oleh negara lain. Indonesia telah mengalami pengklaiman budaya dengan negara tetangga khususnya negara Malaysia sehingga negara harus melakukan sebuah upaya pengenalan kebudayaan yang ia miliki (Lusianti \& Rani, 2012).

Pengenalan budaya diperlukan agar masyarakat siap menghadapi krisis budaya melalui literasi. Pemerintah saat ini sedang menggalakkan berbagai macam literasi mulai dari literasi baca tulis, numerik, sains, digital, finansial, budaya dan literasi kewarganegaraan. Namun masyarakat Indonesia dinilai kurang memahami literasi budaya karena masyarakat kurang memiliki kesadaran atas keberagaman bangsanya (Kementrian Pendidikan dan Kebudayaan, 2017).

Dikatakan Soemardjan

dalam Kurniawan (2012) bahwa kebudayaan ialah, "Suatu sarana dari hasil karya, rasa dan cipta dari masyarakat. Ini berarti kebudayaan tercipta dari masyarakat itu sendiri melalui kebiasaan mereka yang lambat laun menjadi sebuah tradisi dan budaya yang digunakan untuk memahami lingkungan serta menjadi pedoman tingkah laku. Konsep budaya juga dapat 
dicapai dengan belajar dan dibiasakan pada kehidupan bermasyarakat atau sehari-hari (Kistanto, 2017).

Budaya masyarakat di berbagai daerah berbeda-beda, menyesuaikan dengan lingkungan alam sekitar dan pemikiran dari masyarakat tersebut. Hal ini dapat terlihat dari hasil karya mereka seperti kain khas daerah tersebut yang mengandung corak ciri khas lingkungan mereka. Makanan khas mereka yang menyesuaikan dengan hasil alam. Pengetahuan lokal yang ada dalam masyarakat merupakan aset lokal yang tidak dilihat atau intangible asset yang dimiliki oleh suatu masyarakat di daerah tersebut. WIPO (2014) dalam Erza, Yusup, and Erwina (2017) menyatakan bahwa, "Hasil dari pengetahuan lokal yang berupa makanan khas dan pakaian khas merupakan bentuk dari ekspresi masyarakat terhadap lingkungannya."

Walaupun begitu, kenyataannya, "Pengetahuan lokal yang ada di masyarakat belum teralih mediakan ke dalam bentuk karya cetak maupun karya digital." (Yusup \& Saepudin, 2017). Hal ini mendorong sebuah gebrakan unik dalam penyampaian pengetahuan lokal oleh masyarakat serta memperkenalkan pengetahuan lokal ke masyarakat lain. Bukan hanya itu saja, tetapi generasi selanjutnya bisa mengenal pengetahuan lokal daerah mereka.

Untuk itu, artikel ini mengkaji tentang komoditas wahana literasi budaya sebagai wujud pengenalan kebudayaan di Jawa Timur sebagai solusi untuk krisis budaya dan pengklaiman budaya oleh negara lain. Seperti beberapa budaya lokal yang dimiliki masyarakat Jawa Timur dan literasi yang menarik di mata masyarakat. Pemerintah daerah diharapkan bisa memberikan literasi serta mengenalkan kepada masyarakat mengenai pengetahuan lokal atau budaya lokal, sehingga masyarakat bisa mengenal dan mengetahui budaya yang ada di sekitar mereka dan meminimalisir pengklaiman budaya oleh negara lain.

\section{METODE PENELITIAN}

Metode penelitian yang digunakan adalah kualitatif dengan pendekatan penelitian studi literatur. Studi literatur yang dilakukan dengan melakukan pencarian terhadap sumber tertulis berupa buku, artikel dan jurnal yang relevan dengan masalah yang dikaji penulis. Jenis data yang diperoleh saat studi literatur yakni data primer dan sekunder.

Pendekatan kualitatif adalah pendekatan untuk memahami fenomena yang dialami subjek penelitian, misalnya deskriptif dalam bentuk kata-kata dan bahasa, pada suatu konteks khusus yang alamiah dan memanfaatkan berbagai metode alamiah (Moleong, 2010).

$$
\text { Penelitian ini dilakukan }
$$

menggunakan analisis berbagai literatur yang berhubungan dengan kebudayaan lokal masyarakat Jawa Timur dan literasi budaya. Penelitian ini dilakukan untuk menjelaskan pentingnya mengetahui dan mengenal kebudayaan Jawa timur kepada masyarakat.

\section{HASIL DAN PEMBAHASAN}

Budaya merupakan salah satu jiwa dari nilai yang ada di masyarakat. Secara umum pengertian kebudayaan adalah, "Jalan atau arah dalam bertindak dan berpikir untuk memenuhi kebutuhan hidup baik jasmani maupun rohani" (Kurniawan, 2012). Artinya manusia dalam memenuhi kebutuhan jasmani dan rohani melalui cara bertindak dan 
berpikir yang dilakukan secara terusmenerus hingga menjadi kebiasaan dan menjadi budaya masyarakat.

Kebudayaan adalah sarana hasil karya, rasa, dan cipta masyarakat. Soemardi (1964) dalam Kurniawan (2012) menjelaskan bahwa kebudayaan tercipta dari masyarakat itu sendiri melalui kebiasaan mereka yang lambat laun menjadi sebuah tradisi dan budaya yang digunakan untuk memahami lingkungan serta menjadi pedoman tingkah lakunya.

Berdasarkan kedua definisi tersebut bisa disimpulkan bahwa budaya merupakan suatu kebiasaan yang tercipta di masyarakat dan dilakukan secara terusmenerus sehingga menjadi tradisi yang mengakar dan membudaya untuk digunakan dalam hal bertindak dan berpikir sebagai pedoman tingkah laku dalam memahami alam. Manauba (1999) dalam Paneli (2017) menulis bahwa budaya tidak bisa diabaikan masyarakat karena melalui budaya dapat menentukan rutinitas kehidupan masyarakat. Kata lain, masyarakat yang sadar budaya, dia telah menemukan jati diri. Jati diri terbentuk dari pengaruh budaya yang kita anut.

Pengetahuan lokal yang ada dalam masyarakat merupakan aset lokal yang tidak dilihat atau intangible asset yang dimiliki oleh suatu masyarakat di daerah tersebut. Hasil dari pengetahuan lokal yang berupa makanan khas dan pakaian khas merupakan bentuk dari ekspresi masyarakat terhadap lingkungannya (Erza, Yusup, \& Erwina, 2017). Makanan khas dan pakaian khas sebagai pengetahuan lokal dan keterampilan dari masyarakat di daerah tersebut. Keterampilan yang dimaksudkan ialah cara pengolahan dan keunikannya yang berbeda dengan kebudayaan lainnya.
Literasi budaya merupakan kemampuan dalam memahami dan bersikap terhadap kebudayaan Indonesia sebagai identitas bangsa (Kementrian Pendidikan dan Kebudayaan, 2017). Artinya literasi budaya adalah kemampuan seseorang untuk mengenali budaya dan memahami budayanya sendiri. Pelaksanaan literasi budaya merupakan salah satu dari pendidikan sepanjang hayat di masyarakat. Pendidikan sepanjang hayat tidak mengenal batasan usia. Bahkan lansia pun bisa mengikuti kegiatan literasi budaya.

Wujud kebudayaan merupakan salah satu bentuk ekspresi dari pemanfaatan kearifan lokal suatu daerah dan pengetahuan masyarakat dalam mengelola sumber dayanya. Wujud kebudayaan mencakup budaya secara lisan dan produk. Lisan seperti pantun, prosa lama, syair dan lain sebagainya. Selain itu, bentuk produk seperti kain songket, kain batik, nasi padang dan lain sebagainya. Kurniawan mengatakan bahwa wujud kebudayaan terbagi menjadi tiga, di antaranya gagasan (wujud ideal), aktivitas, dan artefak (karya).

Pertama, gagasan (wujud ideal), berbentuk kumpulan ide/gagasan, nilai, norma, peraturan dan sebagainya yang bersifat abstrak. Masyarakat mempunyai ide/gagasan yang tertuang dalam bentuk tulisan, maka idealnya wujud kebudayaan tersebut berupa buku. Jika masyarakat mempunyai ide/gagasan mengenai syair/irama bisa dituangkan ke dalam lagu daerah atau di daerah Jawa sering dikenal sebagai tembang Jawa.

Kedua, aktivitas (tindakan), yang terdiri dari beberapa aktivitas manusia yang saling berinteraksi, kontak sosial serta bergaul berdasarkan adat tata 
kelakuan. Seperti cara komunikasi orang muda dengan orang tua di daerah Jawa, yang lebih dikenal dengan unggah ungguh basa. Ketiga, artefak (karya), berupa hasil dari aktivitas, perbuatan serta karya manusia yang berbentuk benda. Artefak bisa dilihat dan diraba, seperti wayang golek, aktivitas dan perbuatan dari masyarakat waktu itu yang tertuang dalam cerita pewayangan. Lalu bentuk rupa di wayang golek merupakan penggambaran dari manusia di kala itu.

$$
\text { Ketiga komponen wujud }
$$
kebudayaan tidak dapat dipisahkan dan saling terikat dalam kehidupan bermasyarakat. Gagasan (wujud ideal) mengatur dan memberi arah di setiap tindakan ketika beraktivitas. Artefak (karya) merupakan hasil dari keduanya (gagasan dan tindakan). Jika ketiga ini hilang, maka wujud dari kebudayaan tersebut tidak akan berjalan.

Setiap daerah Indonesia memiliki budaya masing-masing yang masih dipertahankan sebagai kekhasan dan dilakukan pada kehidupan sehari-hari. Hal tersebut tentu menjadikan ragam budaya di Indonesia yang secara bersamaan memunculkan berbagai tradisi yang dapat dilihat dari berbagai perspektif, di antaranya: religi, kepahlawanan, adat istiadat, dan alam. Tradisi suatu daerah dapat berwujud dalam berbagai bentuk. Bentuk representasi dari tradisi ini dapat berupa upacara penghormatan, tarian, nyanyian, dan sebagainya (Arwansyah, Sarwiji \& Sahid, 2018).

Budaya lokal merupakan hal utama yang harus dikenali dan dipelajari oleh seseorang yang ingin belajar tentang kebudayaan suatu daerah. Hal itu dikarenakan budaya lokal sebagai suatu identitas daerah yang dipertahankan masyarakat serta dilakukan di kehidupan sehari-hari. Brata (2016) menyatakan kalau, “Budaya lokal menempati posisi sentral sebagai inspirasi dalam penguatan jati diri suatu identitas daerah. Penguatan jati diri ini sangat penting agar diri kita atau masyarakat tidak kehilangan identitas diri sebagai masyarakat di daerah itu."

Wujud kebudayaan di wilayah Jawa Timur yang tertuang dalam bidang kuliner berupa masakan. Indonesia merupakan negara yang terdiri dari beberapa pulau dan ragam suku bangsa. Tyas (2017) menambahkan bahwa, "Makanan tradisional merupakan bagian dari budaya lokal yang berarti termasuk dalam identitas suatu daerah. Yang dikatakan sebagai budayanya ialah tata cara, pengolahan bahan makan, perannya dalam budaya masyarakat seperti perayaan dan resep yang turunmenurun."

Setiap suku bangsa tersebut memiliki karakteristik lingkungan yang berbeda. Perbedaan ini mengakibatkan tradisi yang mereka miliki mempunyai keunikan atau kekhasan sendiri, termasuk masakan khas daerah. Bahan dari masakan menggunakan bahan yang ada di lingkungan sekitarnya untuk digunakan sebagai bahan makanan yang dikonsumsi sehari-hari. Racikan yang dihasilkan dari berbagai jenis bahan dan bumbu mencerminkan seni memasak dari daerah tersebut sehingga menciptakan rasa khas yang menjadikan suatu identitas, contohnya Rawon dari Malang dan Lontong Balap dari Surabaya.

Rawon merupakan masakan dari Jawa Timur yang berasal dari daerah Malang. Sejarah Rawon, berdasarkan hasil analisa penulis, belum ada tulisan yang membahas terkait sejarah rawon 
secara relevan. Namun banyak yang beranggapan bahwa makanan ini adalah makanan raja dahulu yang bermula dari makanan rakyat jelata. Oleh sebab itu, makanan Rawon lebih mudah dikenal karena menjadi bagian dari banyak kalangan.

Gardjito, Putri, and Dewi (2017) menyebutkan bahwa,

"Rawon ialah masakan kuah pekat dengan bumbu utama keluak. Daging yang digunakan pada rawon biasanya daging sapi yang di potong kecil-kecil. Rawon biasa disajikan bersama dengan taoge, telur asin, kerupuk udang dan sambal (Murdijati, 2017)."

Masyarakat Jawa Timur umumnya menyajikan rawon sebagai menu makan siang atau sebagai salah satu menu dalam sebuah acara hajatan. Bumbu khas dari masakan rawon ialah keluak di daerah Jawa Timur sering disebut dengan "kluwek". Bentuk buah keluak besar dan agak lonjong. Daging keluak ini memberikan warna hitam dan rasa gurih yang khas.

Tabel 1

Bahan masakan rawon

\begin{tabular}{|c|c|c|}
\hline Nama & Jumlah & Keterangan \\
\hline $\begin{array}{l}\text { Daging } \\
\text { sapi }\end{array}$ & 750 gram & Dipotong kecil-kecil \\
\hline Keluak & 5 buah & $\begin{array}{l}\text { Direndam, disaring } \\
\text { dan dihaluskan }\end{array}$ \\
\hline Lengkuas & $2 \mathrm{~cm}$ & Memarkan \\
\hline $\begin{array}{l}\text { Daun } \\
\text { salam }\end{array}$ & 3 lembar & \\
\hline Serai & 2 batang & Memarkan \\
\hline $\begin{array}{l}\text { Daun } \\
\text { jeruk } \\
\text { purut }\end{array}$ & 5 lembar & Disobek \\
\hline $\begin{array}{l}\text { Garam } \\
\text { dan gula }\end{array}$ & $\begin{array}{l}\text { Secukupn } \\
\text { ya }\end{array}$ & \\
\hline
\end{tabular}

Berdasarkan tabel 1, bahan masakan rawon terdiri dari daging, keluak, lengkuas, daun salam, serai, daun jeruk, garam, dan gula. Bahan rempahrempah ini akan membantu memberikan rasa tambahan untuk daging dan menghilangkan rasa pekat dari daging.

Perlu diketahui juga bahwa dalam keluak terdapat 6-8 biji berwarna putih kekuningan yang mengandung racun. Untuk menghilangkan racun tersebut, keluak direbus lama lalu direndam dalam tanah dan ditimbuni campuran abu dan daun pisang, sampai warna kulit biji berubah keabuan dan mengeras. Kulit harus dipecahkan sebelum mendapatkan daging biji yang berwarna hitam kecoklatan. Daging keluak yang terasa pahit harus dibuang karena akan memengaruhi cita rasa masakan. Setelah itu, direndam dalam air sampai lunak lalu dihaluskan bersama bumbu yang lain (Ayuningsih, 2017).

Pelengkap dari masakan rawon khas Malang ini bisa ditambahkan dengan telur asin, kecambah, daun kemangi, irisan mentimun dan sambal terasi. Masyarakat Jawa Timur memandang tambahan bahan makanan ini wajib disajikan di ruang makan walaupun bahannya sebagai pelengkap makanan.

Tabel 2

Bumbu halus rawon

\begin{tabular}{lll}
\hline Nama & Jumlah & Keterangan \\
\hline Bawang merah & 6 buah & \\
Cawang putih & 3 siung & \\
tanpa biji & 1 buah & \\
Kunyit & 1 sendok teh & Dicincang \\
Jahe & 1 sendok teh & Dicincang \\
Kemiri & 3 butir & Disangrai/di \\
Ketumbar & 1 sendok teh & Disangrai \\
Terasi matang & $1 / 2$ sendok teh & \\
Air asam & 1 sendok teh & \\
\hline
\end{tabular}


Sesuai tabel 1 dan 2, proses pembuatan masakan rawon sebagai berikut. Kita tuangkan 3-4 sendok makan minyak, tumis bumbu halus, keluak, lengkuas dan semua daun sampai harum. Setelah itu tiriskan bumbu yang telah ditumis. Lalu, kita tuangkan air ke dalam panci sebanyak satu liter dan rebus hingga masak atau daging cukup empuk. Masukkan bumbu yang sudah ditumis ke dalam panci. Kita tunggu sampai mendidih dan matang, lalu hidangkan dengan bahan pelengkap sesuai selera. Ketika kita mengonsumsi masakan rawon sangat lezat dan nikmat apabila disajikan dengan bahan pelengkap yang tertera pada tabel 1.

Lontong balap merupakan masakan khas dari daerah Surabaya. Makanan ini banyak ditemui di setiap tempat di daerah Surabaya. Gardjito, Putri, and Dewi (2017) menceritakan mengenai sejarah lontong balap. Nama Lontong Balap berawal dari peristiwa "balapan" di antara sesama penjual untuk berebut pembeli di Pasar Wonokromo. Dahulu lontong pembalap dijual keliling kota dalam wadah dari tanah liat yang disebut kemaron. Wadah ini cukup berat dan sekarang digantikan dengan panci yang terbuat dari logam. Penjual lontong balap dulu dominan berasal dari kampung Kutisari dan Kedangsari yang sekarang menjadi wilayah Surabaya Selatan. Kampung tersebut berjarak \pm 5 $\mathrm{km}$ dari Pasar Wonokromo. Peristiwa jalan cepat menimbulkan kesan berpacu (dalam bahasa Jawa disebut balapan) yang kemudian menjadi nama lontong balap.

Widodo (2014) dalam Malada, Hartono and Sylvia (2017) malah memiliki pendapat berbeda, nama lontong balap, berawal dari, "Penjual kuliner yang saling balapan atau saling mendahului untuk mengejar halte trem uap di Wonokromo. Mereka selalu iring-iringan ke halte Wonokromo dan selalu mengucapkan 'Ayo balap-balapan'." Lontong balap adalah makanan khas Indonesia yang merupakan ciri khas kota Surabaya di Jawa Timur. Dawood, Jackson, and Yew (2010) mengatakan kalau lontong balap, "A type of rice, nut and bean curd soup". Selain itu, bahan yang khas dalam lontong balap ini ialah lentho, bahan yang terbuat dari kacang tolo dan berbentuk mirip perkedel berukuran sebesar ibu jari (Gardjito, Putri, \& Dewi, 2017).

Alat yang khas dalam pembuatan lontong balap ialah kemaron, yakni wadah dari tanah liat yang digunakan untuk menyimpan makanan yang mengandung kuah. Berikut bahan lontong balap:

Tabel 3

Bahan lontong balap

\begin{tabular}{lll}
\hline Nama & Jumlah & Keterangan \\
\hline $\begin{array}{l}\text { Lontong } \\
\text { Taoge }\end{array}$ & $\begin{array}{l}\text { 3-4 buah } \\
100 \text { gram }\end{array}$ & $\begin{array}{l}\text { Diseduh dengan } \\
\text { air panas }\end{array}$ \\
Sun & 100 gram & $\begin{array}{l}\text { Diseduh dengan } \\
\text { air panas } \\
\text { Dipotong kecil- } \\
\text { kecil }\end{array}$ \\
Tahu & 1 buah & Diiris halus \\
$\begin{array}{l}\text { Daun } \\
\text { bawang }\end{array}$ & 2 buah & \\
\hline
\end{tabular}

Adanya sayuran taoge dan daun bawang pada tabel 3 memberikan rasa segar pada lontong balap.

Tabel 4

Bahan kuah lontong balap

\begin{tabular}{lll}
\hline Nama & Jumlah & Keterangan \\
\hline Daging sapi & 250 gram & $\begin{array}{l}\text { Direbus sampai } \\
\text { empuk }\end{array}$ \\
$\begin{array}{l}\text { Air rebusan } \\
\text { daging }\end{array}$ & $1 \frac{1}{4}$ liter & \\
$\begin{array}{l}\text { Bawang } \\
\text { putih }\end{array}$ & 5 siung & $\begin{array}{l}\text { Digoreng dan } \\
\text { dihaluskan }\end{array}$ \\
$\begin{array}{l}\text { Merica } \\
\text { bubuk }\end{array}$ & $\begin{array}{l}\text { 1/2 sendok } \\
\text { teh }\end{array}$ & \\
& $\begin{array}{l}1 \text { sendok } \\
\text { makan }\end{array}$ & \\
\hline
\end{tabular}


Lontong balap menggunakan kuah yang gurih dari air rebusan daging. Sesuai tabel 4, bahan kuahnya terdiri dari daging sapi, kuah hasil rebusan daging sapi, bawang putih, merica bubuk, dan garam. Proses pembuatan masakan lontong balap sebagai berikut. Kita lumuri tahu dengan garam, potong dadu $1 \mathrm{~cm}$, lalu goreng sampai kecoklatan dan. Kita mendidihkan air rebusan daging bersama bawang putih goreng yang dihaluskan dan semua sisa bahan kuah. Lalu kita kecilkan tungku api, masak sampai kuah sedap. Untuk menguatkan rasa pada masakan lontong balap bisa menambahkan 1-2 sendok teh kaldu sapi bubuk sebelum memasukkan garam. Kita masak hingga matang dan hidangkan sesuai selera.

Tabel 5

Bahan sambal petis lontong balap

\begin{tabular}{lll}
\hline Nama & Jumlah & Keterangan \\
\hline Cabai rawit & $5-6$ buah & Tumbuk halus \\
Petis udang & $\begin{array}{l}\text { 1-2 sendok } \\
\text { makan }\end{array}$ & \\
Jeruk nipis & 1 buah & Diperas \\
Kecap manis & Sesuai selera & \\
\hline
\end{tabular}

Lontong balap agar dimakan tidak terasa anyir dari daging, maka ketika memakannya bisa ditambahkan sambal petis. Adapun bahan bumbu sambal petis sesuai tabel 5, di antaranya cabai rawit, petis udang, jeruk nipis, dan kecap manis. Bahan cabai memberikan rasa pedas, petis udang memberikan rasa gurih udang, jeruk nipis menghilangkan bau amis daging, dan kecap memberikan rasa manis.

Surabaya termasuk daerah wisata kuliner Jawa Timur bagian utara, karena daerah tesebut berada pada wilayah dataran rendah. Adapun Kota Malang merupakan daerah kuliner Jawa Timur bagian Selatan yang berada dalam wilayah yang dekat dengan gunung dan dataran tinggi. Wilayah tersebut cenderung memiliki tanah yang subur dan kaya akan hasil pertanian dan perkebunan. Maka kedua kota ini memiliki makanan yang memiliki cita rasa yang khas, mewakili kondisi daerahnya.

Selain makanan, Indonesia memiliki kekayaan budaya berupa Batik, yang telah dikenal pada zaman nenek moyang atau sejak abad XVII. Lusianti and Rani (2012) mengatakan bahwa,

"Sejarah perkembangannya dari corak-corak lukisan binatang dan tanaman kemudian beralih menyerupai awan, relief candi dan simbol yang menandakan ikon suatu daerah."

Tjahjani (2013) dalam Wangge (2013) pun berpendapat bahwa, Indonesia memiliki berbagai macam kain khas yang unik. Keunikan dari kain khas berasal dari lingkungan sekitar dan aktivitas masyarakat. Di daerah pulau Jawa, kain khas biasa disebut dengan batik. Lisbijanto (2013) mengatakan bahwa,

"Batik berasal dari bahasa Jawa kuno "mbatik", artinya membatik. Batik merupakan hasil karya kerajinan tangan masyarakat Indonesia yang dituangkan dalam selembar kain yang dibuat dengan cara dibatik menggunakan lilin kemudian diproses secara tradisional. Teknik penggunaan cairan malam dilakukan dengan cara menitikkan malam menggunakan alat yang disebut canting."

Canting merupakan alat yang dipakai untuk menuliskan lilin yang telah mencair pada kain yang akan dibuat batik. Canting tradisional terbuat dari tembaga dan bambu sebagai pegangannya. Canting berukuran variatif 
sesuai besar kecilnya motif yang digambar. Yang perlu diketahui dalam penggunaan canting, 1) tiup cucuk canting agar lilin/malam yang ada di dalamnya bisa mengalir keluar, dan 2) torehkan malam/lilin pada kain yang sudah disediakan (Lisbijanto, 2013).

Batik bukan hanya hasil produksi semata, melainkan hasil dari budaya suatu masyarakat dikarenakan batik sangat erat dengan nilai budaya masyarakat. Masyarakat Jawa Timur memiliki beberapa batik di antaranya batik Tuban dan batik Malang.

Batik Gedog merupakan jenis batik yang berasal dari daerah Tuban, Jawa Timur yang merupakan wilayah pesisir di Pulau Jawa. Batik Tuban mempunyai ciri khas tersendiri daripada batik di daerah lainnya. Sejarah batik Tuban di mulai pada zaman Kerajaan Majapahit dan berkembang hingga saat ini. Motif ataupun corak pada batik Tuban menggambarkan simbol dari ketiga budaya, yakni budaya Jawa, budaya Islam dan budaya Tiongkok. Budaya Jawa dan budaya Islam dapat dilihat dari ornamen yang bernuansa religius, sedangkan budaya Tiongkok dapat dilihat dari motif gambar burung Hong (Lisbijanto, 2013).

Batik Gedog mirip batik pada umumnya, namun yang membedakan ialah kain tenun yang digunakan untuk membatik. Nanik (2017) dalam Kartikasari (2017) mengatakan bahwa, “Batik ini memiliki keunikan yakni kain tenun yang dibatik oleh masyarakat Tuban." Batik Gedong dari Tuban merupakan jenis batik khas dari Tuban. Lisbijanto (2013) mengatakan, “Asal nama Gedong berasal dari bunyi ‘Dog Dog Dog’ yang muncul dari bunyi alat pemintal tenun yang digunakan untuk membuat batik. Bahan kain yang akan digunakan dipintal langsung dari kapas dan dipintal menjadi benang kemudian ditenun menjadi kain."

Uswatun (2017) dalam Kartikasari (2017) menambahkan,

"Masyarakat Tuban percaya bahwa batik Gedog telah ada di zaman kerajaan Majapahit pada masa kepemimpinan Adipati Ronggolawe. Hal itu dapat dibuktikan dengan banyaknya motif panji-panjian pada batik Gedog. Batik Gedog ini digunakan untuk membedakan kasta di zamannya."

Selain itu, Lisbijanto (2013) menceritakan bahwa filosofi motif batik Gedong: motif burung hong pada batik Tuban dipengaruhi oleh budaya Tiongkok. Masyarakat Tuban meyakini kalau motif panji krentil, panji serong dan panji konang dapat menyembuhkan penyakit, sehingga banyak masyarakat Tuban yang memiliki batik tersebut.

Adapun proses pembuatan Batik Gedog memiliki 7 tahapan yang dilakukan dalam pembuatan batik secara tradisional (Lisbijanto, 2013). Tahapan Tersebut tertuang dalam tabel 6. 
Tabel 6

Tahapan pembuatan batik gedog

\begin{tabular}{|c|c|}
\hline Tahapan & Proses \\
\hline 1 & $\begin{array}{l}\text { "Mbathik atau nglowong", } \\
\text { membuat pola atau motif pada } \\
\text { kain dengan cara menutup kain } \\
\text { dengan menggunakan malam } \\
\text { dengan alat canting. Setelah itu } \\
\text { dilanjutkan dengan "nerusi" atau } \\
\text { melanjutkan hingga menyeluruh. }\end{array}$ \\
\hline 2 & $\begin{array}{l}\text { "Nembok", menutupi bagian pola } \\
\text { atau motif yang akan dibiarkan } \\
\text { berwarna putih sesuai dengan } \\
\text { warna kain dengan menggunakan } \\
\text { malam. }\end{array}$ \\
\hline 3 & $\begin{array}{l}\text { "Medel", mencelup kain yang } \\
\text { telah diberi malam ke dalam } \\
\text { pewarna untuk memberikan } \\
\text { warna dasar. Lalu dilakukan } \\
\text { berulangkali yang nantinya kain } \\
\text { tersebut akan mempunyai warna } \\
\text { dasar. }\end{array}$ \\
\hline 4 & $\begin{array}{l}\text { "Ngerok dan nggirah", } \\
\text { menghilangkan malam yang } \\
\text { masih menempel di kain, di mana } \\
\text { bagian ini akan diberi warna soga. } \\
\text { Pada tahap ngerok menggunakan } \\
\text { alat cawuk semacam pisau } \\
\text { tumpul. }\end{array}$ \\
\hline 5 & $\begin{array}{l}\text { "Mbironi", menutup bagian kain } \\
\text { yang akan tetap berwarna dasar } \\
\text { dengan menggunakan malam. } \\
\text { Proses ini dilakukan di kedua sisi } \\
\text { kain. }\end{array}$ \\
\hline 6 & $\begin{array}{l}\text { "Nyoga", mencelup kain ke dalam } \\
\text { pewarna soga. Lakukan } \\
\text { berulangkali sehingga hasil } \\
\text { menjadi baik. Setiap mencelupkan } \\
\text { ke warna harus dikeringkan } \\
\text { dahulu lalu dicelupkan kembali. }\end{array}$ \\
\hline 7 & $\begin{array}{l}\text { "Nglorod", menghilangkan malam } \\
\text { yang menempel di kain } \\
\text { menggunakan air mendidih, } \\
\text { setelah itu baru dijemur. Dan } \\
\text { selesai. }\end{array}$ \\
\hline
\end{tabular}

Selain Batik Gedog dari Tuban, Jawa Timur ada juga batik malangan. Dwipasari and Subianto (2017) mengatakan, "Batik buatan dari kota Malang (biasa disebut batik Malangan) hingga saat ini masih belum begitu dikenal masyarakat Indonesia seperti batik Jawa lainnya karena masih relatif baru." Sejarah dari batik Malangan yakni, batik Kota Malang sudah dibuat sekitar tahun 1900-an dan sering dipakai dalam upacara adat. Batik di Malang sering disebut batik Malangan.

Sunaryo (2009) dalam Permana, Mustikawati, and Laksmiwati (2015) memiliki menjelaskan bahwa batik Malangan mempunyai ciri utama yakni. "Pertama motif hias tumbuhan: berkaitan dengan kekayaan flora sekitar (Kembang padma, Kembang Kopi, kembang Mayang, Sawat dan Kembang Piring), kedua Motif hias manusia: berkaitan dengan budaya dan sejarah (Motif Tugu, Candi Jago, Candi Tikus, Topeng Malangan, Buah-buahan khas Batu dan Keramik Dinoyo), ketiga Motif binatang: berkaitan dengan binatang maskot (Motif Singo, Ayam Bekisar dan Jalak Ijo), keempat Motif benda alam seperti Motif Sapu Ular, dan (5) Motif sosial seperti Motif Kembang Api."

Sesuai filosofinya, motif batik Malang kucecwara memiliki komposisi motif yakni mahkota, tugu Malang, rumbai singa, archa, bunga teratai, sulursulur juga isen-isen belah ketupat. Mahkota menggambarkan bentuk mahkota dari Raja Gajayana yang pernah membawa kerajaan Gajayana menuju puncak kejayaan. Batik Malang diharapkan mampu meraih puncak kejayaan dalam perjalanan hidupnya layaknya puncak kejayaan Raja Gajayana dahulu. Tugu Malang menggambarkan kekuasaan wilayah, artinya wujud keperkasaan dan ketegaran kota Malang. Rumbai Singa menyimbolkan budaya masyarakat yang berjiwa pemberani dengan semangat membara dan pantang menyerah seperti singa. Bunga Teratai merupakan pelambangan dari suatu keindahan alam yang penuh kesuburan. 
Arca yang tergambar arca Candi Singosari yang merupakan aset budaya Malang serta mengingatkan tentang kejayaan dari Candi Singosari. Isen - isen belah ketupat ini menggambarkan Candi Badut yang memiliki makna bahwa manusia bukanlah makhluk yang sempurna.

Proses pembuatan batik Malang hampir sama pembuatannya dengan batik tulis lainnya. Perbedaannya terletak dalam bentuk motif yang khas dari batik Malangan. Batik dahulu lebih sering dipakai saat upacara adat atau kegiatankegiatan formal. Setiap motif pada kain batik di setiap daerah memiliki makna masing-masing bahkan ada sebuah kepercayaan untuk menyembuhkan penyakit seperti kain batik asal Tuban.

Munculnya desainer seperti Zaskia Sungkar dan Ivan Gunawan telah memperkenalkan mode berpakaian yang trendi dan terlihat estetik dalam mengenakan kain khas. Dukungan teknologi informasi dan sosial media sebagai alat komunikasi pun mengubah pola pikir penggunaan batik yang tidak hanya digunakan saat acara adat atau acara formal, contohnya penggunaan batik lebih meluas seperti batik untuk keseharian dan pakaian bekerja.

Pengetahuan lokal yang beredar di Masyarakat Jawa Timur seperti makanan khas daerah dan kain khas telah menjadi sebuah produk lokal. Hal ini di masyarakat Jawa Timur secara umum telah masuk ke dalam informasi secara konten dan media representasi (Erza, Yusup, \& Erwina, 2017). Konten yang dimaksudkan ialah informasi mengenai sejarah, filosofi, alat dan bahan yang digunakan, proses pembuatan hingga pemanfaatan hasil produk lokal tersebut. Adapun media representasi yang dimaksudkan adalah tempat untuk menuangkan pengetahuan lokal seperti kain pada batik.

Masyarakat Jawa Timur memerlukan sebuah inovasi untuk memaksimalkan penyampaian informasi mengenai pengetahuan lokal. Namun ternyata, masyarakat Indonesia belum mengonversikan pengetahuan lokal ke dalam bentuk karya cetak maupun karya digital (Yusup \& Saepudin, 2017). Padahal pendokumentasian yang baik akan memudahkan masyarakat dalam melakukan inovasi. Hal ini mendorong masyarakat untuk membuat gebrakan unik dalam penyampaian pengetahuan lokal dan memperkenalkannya ke masyarakat lain. Bukan hanya itu saja, generasi selanjutnya pun bisa mengenal pengetahuan lokal daerah mereka sendiri.

Banyak sekali tempat wisata yang menarik di wilayah Jawa Timur untuk dikunjungi seperti Jatim Park 1, 2 dan 3. Ketiga tempat wisata tersebut menawarkan wahana yang bisa menghibur dan menambah wawasan seperti di Jatim Park 1 dan 2, sedangkan Jatim Park 3 sebagai tempat yang nyaman untuk berburu foto yang unik. Berdasarkan konsep wisata ini, ternyata telah memberikan wahana dan informasi yang menarik bagi masyarakat.

Pada era globalisasi muncul istilah commodification, atau proses perubahan barang atau layanan yang sebelumnya mengikuti aturan sosial non-pasar menjadi suatu subjek yang mengikuti aturan pasar. Commodification merupakan salah satu bentuk kapitalisme global mengakumulasi kapital. Hal ini telah mentransformasikan nilai guna menjadi nilai tukar yang sifatnya komersial (Irianto, 2016). Model literasi budaya berupa pariwisata sangat dianjurkan untuk mengenalkan budaya lokal serta 
mengurangi pengklaiman budaya oleh negara lain.

Gidden (2012) dalam Pratiwi and Pinasti (2017) menyatakan kalua "Nilai strategis budaya lokal dapat dijadikan sebagai pengembangan pariwisata, yang sejalan dengan pengembangan budaya dan semangat manusia beserta cipta, rasa dan karsanya."

Berdasarkan hal ini, budaya lokal dapat digali dan dikembangkan lebih jauh. Dikatakan Griya Boedaya sebagai pembelajaran sepanjang hayat pada masyarakat di daerah Jawa Timur. Griya Boedaya memunculkan konsep tempat wisata yang edukatif yang berasal dari pengetahuan lokal masyarakat Jawa Timur, dari semua kalangan usia di masyarakat.

Pelaksanaan literasi budaya sangat beragam, bisa melalui membaca literatur tentang budaya, menonton pameran budaya dan menonton beberapa video yang berkaitan dengan budaya. Salah satu inovasi dalam literasi budaya yang kami angkat yakni Griya Boedaya. Griya Boedaya merupakan tempat wisata pengenalan budaya lokal seperti kain khas daerah dan masakan daerah. Filosofi dari nama Griya Boedaya diambil dari kata griya yang dalam bahasa Jawa berarti rumah dan boedaya yang diambil dari kata budaya ejaan lama. Mengapa mengambil konsep rumah? Karena ke mana pun orang pergi, pasti orang tersebut akan kembali ke rumah. Masyarakat mengharapkan melalui konsep rumah ini diharapkan akan terus orang berkunjung ke Griya Boedaya untuk mengenal jati diri mereka.

Wahana yang ditampilkan pada Griya Boedaya meliputi pengenalan sejarah, proses penciptaan dan filosofi, sistem pengerjaan, alat yang digunakan dan penggunaan dari produk budaya setempat. Griya Boedaya juga memiliki tour guide untuk memandu pengunjung di antaranya, pengenalan sejaran, proses penciptaan dan filosofi, alat dan bahan, sistem pengerjaan, dan penggunaan.

Pertama, pengenalan sejarah merupakan wahana dalam ruangan yang memberikan informasi mengenai sejarah dari salah satu kebudayaan yang ada di daerah Jawa Timur. Ruang pengenalan sejarah merupakan ruang yang kedap suara dan memiliki layar monitor dan terdapat sound system. Pembuatan video atau gambar yang berkaitan dengan sejarah termasuk ke dalam salah satu kebudayaan. Sound system sebagai penunjang audio dari video tersebut dan pemandu sebagai pembicara dalam pengenalan kebudayaan. Capaian utama wahana ini ialah masyarakat bisa mengetahui dan memahami sejarah dari salah satu kebudayaan yang dimiliki oleh Jawa Timur.

Kedua, proses penciptaan dan filosofi merupakan wahana yang menampilkan informasi bagaimana proses penciptaan hasil dari pengetahuan lokal di masyarakat Jawa Timur. Ruang proses penciptaan merupakan ruang yang kedap suara dan memiliki layar monitor dan monitornya, Sound System. Sistem di ruangan ini sama dengan ruang pengenalan sejarah. Yang membedakan hanya informasi yang disampaikannya. Capaian utama dari wahana ini ialah masyarakat bisa mengetahui dan memahami proses penciptaan dan filosofi dari pengetahuan lokal Masyarakat Jawa Timur.

Ketiga, alat dan bahan merupakan peralatan dan perlengkapan yang harus ada untuk membuat suatu produk. Wahana alat dan bahan berisikan alat dan 
bahan dari hasil kebudayaan masyarakat Jawa Timur. Ruangan ini layaknya museum, beberapa alat dan bahan dibuat miniatur dan yang lainnya hanya berupa gambar. Alat dan bahan yang dibuat miniatur berupa alat dan bahan yang khas. Kemudian, disamping rak terdapat layar kecil untuk menampilkan video, yang berisikan penggunaan dan fungsi alat/bahan tersebut. Capaian utama wahana alat dan bahan ini ialah masyarakat bisa mengetahui, dan memahami peralatan dan perlengkapan yang dibutuhkan untuk membuat produk dari hasil pengetahuan lokal.

Keempat, sistem pengerjaan pada wahana ini ditujukan kepada pengguna untuk mengetahui sistem pengerjaan suatu produk hasil dari pengetahuan lokal masyarakat Jawa Timur. Ruang sistem pengerjaan dirancang khusus untuk mempraktikkan proses pembuatan dari hasil kebudayaan. Ruangan ini menyediakan alat dan bahan, pemandu, dan perlengkapan hasil kebudayaan. Pemandu dalam sistem pengerjaan ini ialah orang yang ahli untuk membantu pengunjung mempraktikkan proses pembuatan suatu hasil kebudayaan. Capaian utama wahana ini ialah masyarakat bisa mempraktikkan secara langsung proses pembuatan dengan arahan dari masyarakat yang ahli dan bekerja di Griya Boedaya.

Kelima, penggunaan merupakan wahana terakhir yang dimiliki Griya Boedaya, yang mengajarkan tentang cara penggunaan produk pengetahuan lokal masyarakat Jawa Timur. Ruangan penggunaan berisi produk dari hasil kebudayaan dan ditampilkan dalam beberapa bentuk. Untuk kain khas ditampilkan dalam mannequin serta menampilkan penggunaan di waktu dulu dan sekarang. Adapun makanan daerah ditampilkan dalam miniatur orang dan tempat makan secara prasmanan, yang digambarkan pemanfaatannya ketika dulu dan sekarang.

Pengunjung untuk masuk ke dalam wahana Griya Boedaya harus membeli tiket, yang terbagi menjadi 2 kategori. Kategori umum dan kategori khusus. Bagi masyarakat yang membeli tiket kategori umum, mereka medapatkan fasilitas untuk mengunjungi 4 wahana yakni pengenalan sejarah, proses penciptaan dan filosofi, alat dan bahan, dan sistem pengerjaan. Masyarakat yang membeli tiket kategori khusus mendapatkan fasilitas untuk mengunjungi 5 wahana yakni pengenalan sejarah, proses penciptaan dan filosofi, alat dan bahan, sistem pengerjaan dan penggunaan serta mendapatkan souvenir dan makan dari Griya Boedaya. Setiap rombongan pengunjung akan didampingi oleh tour guide.

\section{SIMPULAN}

Kebudayaan dianggap sebagai aset bangsa yang tak ternilai harganya. Kebudayaan sebagai salah satu sumber pengetahuan masyarakat dalam mengenal tradisi dan sejarah suatu daerah. Globalisasi membawa pengaruh terhadap kebudayaan yang beriringan dengan modernisasi yang telah menyebar ke seluruh penjuru dunia dalam revolusi sosial atau masuk ke semua sudut kehidupan seperti mengaburkan batas tradisional. Masyarakat telah mengalami krisis budaya dan adanya pengklaiman budaya oleh negara lain. Kondisi krisi bisa dikurangi melalui literasi budaya yang menarik seperti wisata kebudayaan. Pariwisata mengenai budaya lokal ini sangat efektif dilakukan, atau disebut 
sebagai commodification, yang akan membuka peluang dalam memperkenalkan budaya lokal kepada masyarakat. Masyarakat pun dapat mengetahui dan memahami kebudayaan sendiri. Untuk penelitian selanjutnya, fenomena literasi budaya perlu dapat diperluas melalui salah satu produk kearifan lokal.

\section{DAFTAR PUSTAKA}

Arwansyah, Y. B., Sarwiji, S., \& Sahid, T. W. (2018). Analyzes the meaning and symbols in stages Yaqowiyu tradition in Klaten. In 3rd International Conference on Art, Language, and Culture (ICALC) 2018. Solo: Perkumpulan

Agroteknologi/Agroekoteknologi Indonesia (PAGI).

Arwansyah, Y. B., Suwandi, S., \& Widodo, S. T. (2017). Revitalisasi peran budaya lokal dalam materi pembelajaran bahasa Indonesia bagi penutur asing (BIPA). In Proceedings of Education and Language International Conference (pp. 915-920). Semarang: UNISSULA. Retrieved from http://jurnal.unissula.ac.id/index.p hp/ELIC/article/view/1318/1025

Ayuningsih, S. F. (2017). Pelestarian Rawon Nguling Sebagai nilai tambah pada pengembangan wisata kuliner tradisional Indonesia. Bijak: Majalah Ilmiah Institut STIAMI, 14(1), 108-126. https://doi.org/10.31334/bijak.v14i1 .64 .956

Brata, I. B. (2016). Kearifan budaya lokal perekat identitas bangsa. Jurnal Bakti Saraswati (JBS), 5(1), 9-16. Retrieved from

http://jurnal.unmas.ac.id/index.php /Bakti/article/view/226/201

Dawood, R., Jackson, S. J., \& Yew, J.
(2010). Supporting the information needs of mobile microentrepreneurs in the developing world: The case of Indonesian food cart vendors. In Proceedings of the 4th ACM/IEEE International Conference on Information and Communication Technologies and Development - ICTD '10 (pp. 1-10). London: ACM Digital Library. https://doi.org/10.1145/2369220.236 9226

Dwipasari, L., \& Subianto, T. (2017). Pendampingan pengembangan KUB (Kelompok Usaha Bersama) Batik Malangan Kota Malang. Jurnal Pengabdian Kepada Masyarakat, 2(2), 42-50. Retrieved from http://jurnal.unmer.ac.id/index.php /jpkm/article/view/1816

Erza, E. K., Yusup, P. M., \& Erwina, W. (2017). Komunikasi budaya masyarakat Pandai Sikek dalam melakukan transformasi pengetahuan lokal. Kajian Informasi $\mathcal{E}$ Perpustakaan, 5(2), 141-154. https://doi.org/10.24198/jkip.v5i2.1 0716

Gardjito, M., Putri, R. G., \& Dewi, S. (2017). Profil struktur, bumbu, dan bahan dalam kuliner Indonesia. Yogyakarta: Gadjah Mada University Press.

Irianto, A. M. (2016). Komodifikasi budaya di era ekonomi global terhadap kearifan lokal: Studi kasus eksistensi industri pariwisata dan kesenian tradisional di Jawa Tengah. Jurnal Theologia, 27(1), 213-236. https://doi.org/10.21580/teo.2016.2 7.1.935

Kartikasari, D. W. (2017). Makna motif Batik Gedog sebagai refleksi karakter masyarakat Tuban. Jurnal Kajian Moral Dan Kewarganegaraan, 5(3), 
960-974. Retrieved from https:/ /jurnalmahasiswa.unesa.ac.id /index.php/jurnal-pendidikan-

kewarganegaraa/article/view/21959 /20126

Kementrian Pendidikan dan Kebudayaan. (2017). Materi pendukung literasi budaya dan kewargaan: Gerakan literasi nasional. Retrieved November 10, 2018, from http://gln.kemdikbud.go.id/glnsite /wpcontent/uploads/2017/10/literasiBUDAYA-DAN-KEWARGAAN.pdf

Kistanto, N. H. (2017). Tentang konsep kebudayaan. Sabda: Jurnal Kajian Kebudayaan, 10(2), 1-11. https://doi.org/10.14710/sabda.10.2 .$\% 25 p$

Kurniawan, B. (2012). Ilmu budaya dasar. Tangerang: Jelajah Nusa.

Lisbijanto, H. (2013). Batik. Yogyakarta: Graha Ilmu.

Lusianti, L. P., \& Rani, F. (2012). Model diplomasi terhadap UNESCO dalam mematenkan batik sebagai warisan budaya Indonesia tahun 2009. Jurnal Transnasional, 3(2), 1-15. Retrieved from

https:/ / ejournal.unri.ac.id/index.ph p/JTS/article/view/72

Malada, C. A., Hartono, D. D., \& Sylvia, M. (2017). Perancangan visual branding Lontong Balap Pak Gendut sebagai kuliner khas Surabaya. Jurnal DKV Adiwarna, 1(1), 11-21. Retrieved from

http:/ / publication.petra.ac.id/index. php/dkv/article/view/5494/5025

Moleong, L. J. (2010). Metodologi penelitian kualitatif. Bandung: Rosda Karya.

Mubah, A. S. (2011). Strategi meningkatkan daya tahan budaya lokal dalam menghadapi arus globalisasi. Masyarakat, Kebudayaan Dan Politik, 24(4), 302-308.

Paneli, D. W. W. (2017). Transformasi pertunjukkan wayang orang komunitas Graha Seni Mustika Yuastina Surabaya. JADECS, 2(2), 7497. Retrieved from http:/ /journal2.um.ac.id/index.php /dart/article/view/2185/1287

Permana, C. Mustikawati, T., \& Laksmiwati, T. (2015). Karakter warna batik Malangan sebagai dasar desain interior Galeri Batik Malangan. Jurnal Mahasiswa Jurusan Arsitektur, 3(2), 1-12. Retrieved from http:/ / arsitektur.studentjournal.ub.a c.id/index.php/jma/article/view/11 $1 / 108$

Pratiwi, B. D., \& Pinasti, V. I. S. (2017). Pariwisata dan budaya: Studi peran serta masyarakat lokal dalam pengelolaan pariwisata di Kampung Pitu, Nglaggeran, Patuk, Gunung Kidul. E-Societas: Jurusan Pendidikan Sosiologi, 6(8), 1-11. Retrieved from http://journal.student.uny.ac.id/ojs/i ndex.php/societas/article/view/9147 /8818

Suneki, S. (2012). Dampak globalisasi terhadap eksistensi budaya daerah. Jurnal Ilmiah CIVIS, 2(1), 307-321. Retrieved from http://journal.upgris.ac.id/index.ph p/civis/article/view/603/553

Tyas, A. S. P. (2017). Identifikasi kuliner lokal Indonesia dalam pembelajaran bahasa Inggris. Jurnal Pariwisata Terapan, 1(1), 1-14. https://doi.org/10.22146/jpt.24970

Wangge, J. (2013). Perancangan kampanye pelestarian batik belanda sebagai akulturasi kebudayaan Indonesia (Skripsi). Universitas Kristen Maranatha, Bandung. Retrieved from 
https:/ / repository.maranatha.edu/1 3027/

Yusup, P. M., \& Saepudin, E. (2017). Praktik literasi informasi dalam proses pembelajaran sepanjang hayat. Kajian Informasi $\mathcal{E}$ Perpustakaan, 5(1), 79-94. https:// doi.org/10.24198/jkip.v5i1.1 1387 